\title{
Soil bacterial strains able to grow on the surface of oxidized polyethylene film containing prooxidant additives
}

\author{
Marek Koutnya, Pierre Amato ${ }^{b}$, Marketa Muchova ${ }^{a}$, Jan Ruzicka ${ }^{a}$ and Anne-Marie Delort ${ }^{b}$ \\ ${ }^{a}$ Department of Environmental Protection Engineering, Faculty of Technology, Tomas Bata University in \\ Zlin, TGM sqr. 275, 76272 Zlin, Czech Republic \\ ${ }^{b}$ Laboratoire de Synthese Et Etude de Systemes a Interet Biologique (SEESIB), UMR 6504 CNRS, \\ Ensemble Universitaire des Cezeaux, Universite Blaise Pascal, 63177 Aubiere Cedex, France
}

\begin{abstract}
Twelve bacterial strains able to adsorb and grow on the surface of oxidized low-density polyethylene film containing prooxidant additives were isolated from three forest soils and subsequently identified. Most of them belonged to different genera of the proteobacteria group; however, three of the isolates were Rhodococcus strains. With the exception of one of the Rhodococcus strains, the isolates did not exhibit significant hydrophobicity of their cell surfaces. The study showed that bacteria capable of adhering to the surface of oxidized polyethylene, growing there and possibly biodegrading its oxidation products are not rare in forest soils and that they belong to different taxonomical groups common in soil environment.
\end{abstract}

Keywords: Polyethylene; Biodegradation; Soil; Prooxidants; Bacteria; Hydrophobicity

\section{Introduction}

In the last few years, polyethylene (PE) films containing prooxidant additives have been introduced onto the market as a new material promising biodegrability, in conjunction with the continual use of existing production and processing technologies and with reasonable prices of products (Wiles and Scott, 2006). Primary applications are in agricultural greenhouse construction, mulching films, packaging films as well as in other products with a limited lifetime, e.g. bags. These articles are intended to be biodegradable in soil or during composting. As yet, only a little data exists to support the idea of such materials' biodegradability ([Chiellini et al., 2003], [Chiellini et al., 2007] and [Jakubowicz, 2003]). However, the microbiology of the process remains almost completely unknown. Here, an attempt was made to isolate, identify and partially characterize soil microbial species able to adsorb and grow on the surface of oxidized low-density PE film containing prooxidant additives. The microorganisms attached to the surface of the material could extract and utilize oxidation products of PE, a broad spectrum of compounds; mainly various fatty acids like substances, but other functionalities like esters, ketones, alcohols and double bonds can also be found ([Albertsson et al., 1995] and [Khabbaz et al., 1999]). Thus 
the adherent microorganisms can be regarded as a potential biological agent in the proposed scheme for degradation of PE with prooxidant additives (Koutny et al., 2006b). So far, the most often investigated bacteria in relation to PE degradation were different members of Actinobacteria, above all various Rhodococcus strains ([Orr et al., 2004], [Sivan et al., 2006] and [Koutny et al., 2006b]). But, completely different taxonomical groups were also reported like e.g. pseudomonads or bacilly ([Albertsson et al., 1993] and [Sudhakar et al., 2008].). A previously described preoxidized low-density PE film containing prooxidant additives was used throughout this study (Koutny et al., 2006a). The described preoxidation treatment should simulate several years' exposure of the material to outdoor conditions.

\section{Material and methods}

Preoxidized PE film was transparent LDPE film $60 \mathrm{~mm}$ thick containing prooxidant additives based on organometallic complexes. To balance the prodegradant activity phenolic antioxidants were used in the blends. The sample was exposed for $120 \mathrm{~h}$ in the accelerated photoageing chamber SEPAP 12.24 $\left(\lambda \geq 300 \mathrm{~nm}, 60 \pm 1{ }^{\circ} \mathrm{C}\right)$. After the exposure in SEPAP the samples were considered sterile and treated in a sterile way. Exposure in SEPAP was followed by $300 \mathrm{~h}$ of exposure in an aerated oven at $60{ }^{\circ} \mathrm{C}$. For the examined PE film $100 \mathrm{~h}$ of exposure in SEPAP 12.24 corresponds to 3 months weathering under European outdoor conditions in the period from March to October and incubation in the oven was equivalent to 2-3 years of incubation at room temperature in the dark (particles buried in the soil or particles not exposed to sunlight). See Koutny et al. (2006b) for more details. PE film preoxidized in this way, already highly fragmented and very fragile, was passed through a metallic screen with eye diameters of about $1 \mathrm{~mm}$ to obtain uniform fragments for further work.

Upper horizons of three different forest soils sampled above Clermont-Ferrand (France) were chosen as the source materials (Table 1). An upper soil horizon to a depth of about $10 \mathrm{~cm}$ was sampled using a sterile knife, after removing undegraded plant debris and a surface layer of approximately $2 \mathrm{~cm}$. Three sub-samples were taken at each location and then pooled in a sterile plastic bag. The final weight of samples was about $200 \mathrm{~g}$.

Table 1.

Characterization of investigated soil samples.

\begin{tabular}{|l|l|l|l|l|}
\hline & pH (KCl) & Organic content & Altitude & Dominant tree species \\
\hline Soil 1 & 3.6 & $52 \%(1.0)$ & $680 \mathrm{~m}$ & Picea sp. \\
\hline Soil 2 & 5.1 & $28 \%(3.2)$ & $705 \mathrm{~m}$ & Quercus sp., Carpinus $\mathrm{sp}$. \\
\hline Soil 3 & 5.1 & $23 \%(2.8)$ & $725 \mathrm{~m}$ & Quercus sp., Robinia $\mathrm{sp}$. \\
\hline
\end{tabular}

Standard deviations are in parentheses; $n=3$. 
Soil microorganisms were first released from soil particles into suspension solution. $10 \mathrm{~g}$ of aseptically weighed soil was added to $100 \mathrm{ml}$ of suspension solution (Tween $801.5 \mathrm{~g} \mathrm{l}^{-1} ; \mathrm{Na}_{4} \mathrm{P}_{2} \mathrm{O}_{7} 4.0 \mathrm{~g} \mathrm{l^{-1 }} ; \mathrm{NaCl}$ $5.0 \mathrm{~g} \mathrm{l}^{-1}$ ) and the mixture was vigorously shaken for $30 \mathrm{~min}$. Then $100 \mu \mathrm{l}$ of the suspension was inoculated into $50 \mathrm{ml}$ of basic mineral salt medium $\left(3.8 \mathrm{~g} \mathrm{Na}_{2} \mathrm{HPO}_{4} \times 12 \mathrm{H}_{2} \mathrm{O}, 1.8 \mathrm{~g} \mathrm{KH}_{2} \mathrm{PO}_{4}, 0.02 \mathrm{~g}\right.$ $\mathrm{MgSO}_{4} \times 7 \mathrm{H}_{2} \mathrm{O}, 0.03 \mathrm{~g} \mathrm{Fe}\left(\mathrm{NH}_{4}\right)_{2}\left(\mathrm{SO}_{4}\right)_{2} \times 6 \mathrm{H}_{2} \mathrm{O}, 0.01 \mathrm{~g} \mathrm{CaCl}_{2} \times 2 \mathrm{H}_{2} \mathrm{O}, 0.5 \mathrm{~g} \mathrm{NaCl}, 0.3 \mathrm{~g} \mathrm{NH} 4 \mathrm{Cl}$ and $1 \mathrm{ml}$ of trace element solution per litre (Vaclavkova et al., 2007), all chemicals purchased from Sigma-Aldrich) containing $100 \mathrm{mg}$ of fine fragments of preoxidized PE film in $250 \mathrm{ml}$ Erlenmayer flask. Although the soils were rather acidic, $\mathrm{pH} 7$ was chosen for the medium, a value which is tolerated well by the majority microorganisms. Cultures were incubated for 30 days with gentle shaking $(20 \mathrm{rpm})$ at $20^{\circ} \mathrm{C}$. After this period, small aliquots (about $5 \mathrm{mg}$ ) of PE fragments were collected and transferred into $1.5 \mathrm{ml}$ tubes and repeatedly washed (maximum of liquid was drained out with a pipette, 1.5 of fresh mineral medium was added and the suspension briefly mixed on a vortex, this was repeated eight times) in order to wash out all planktonic (non-adherent) microorganisms. Afterwards, the PE fragments were spread on three types of agar media: on R2A agar (Difco) to recover adhered bacterial species; on Emerson agar (Difco), initially intended mainly to report fungi and actinomycetes; and on Sabouraud agar (Difco) for fungi and yeast species. Plates were incubated 10 days at $25^{\circ} \mathrm{C}$. Following this, individual microbial strains were isolated on the basis of different colony appearance and observed growth rates and designated with codes beginning S1, S2 and S3 according to the soil of their origin and a letter R, E or S, in the middle, according to the particular agar media of their isolation. Purity of each strain was checked on a fresh streak plate and microscopically (after Gram staining). Once they had been isolated, each pure strain was again inoculated into $50 \mathrm{ml}$ of basic mineral salt medium containing $100 \mathrm{mg}$ of fine fragments of preoxidized PE film. The initial cell density was set at $10^{4}$ cells per millilitre on the basis of cell counting on a microscope. After 30 days at $25^{\circ} \mathrm{C}$, microbial growth on the surface of preoxidized PE was confirmed by optical microscopy after simple fixation ( $4 \%$ formaldehyde, $2 \mathrm{~h}$ at $\left.4{ }^{\circ} \mathrm{C}\right)$ and staining with safranine. Growth was judged as significant if $\sim 10^{2}$ or more cells appeared on the material's surface in every microscope field. Strains excluded from further investigation, on the other hand, exhibited no growth, or there were observed only rare individual cells. Because the PE fragments were quite irregular in shape and size it would have been extremely difficult to count the cells and evaluate microscopically the growth in a strictly quantitative way, e.g. cells per $\mathrm{mm}^{2}$. Therefore, the density of the surface coverage for individual strains was evaluated semi-quantitatively by optical microscopy (mag. 1000×) on the scale 1-3: $1,10^{2}$ cells/field or individual microcolonies; 2, many microcolonies in every microscope field, sometimes in contact; 3 , larger areas of complete surface coverage in every microscope field (Table 2).

Table 2.

Isolated and identified stains and their hydrophobicity using BATH assay.

Identification \% Homology, (bp
sequenced)
Taxonomical group
BATH

R2A, (\%)
BATH

HEX, (\%) 


\begin{tabular}{|c|c|c|c|c|c|c|}
\hline Identification & Code & $\begin{array}{l}\% \text { Homology, (bp } \\
\text { sequenced) }\end{array}$ & $\begin{array}{l}\text { Taxonomical } \\
\text { group }\end{array}$ & Growth & $\begin{array}{l}\text { BATH } \\
\text { R2A, (\%) }\end{array}$ & $\begin{array}{l}\text { BАTH } \\
\text { HEX, (\%) }\end{array}$ \\
\hline Ralstonia sp. & S1R1 & $98 \%(493)$ & $\begin{array}{l}\text { Beta- } \\
\text { proteobacteria }\end{array}$ & 2 & $13(1.4)$ & $\mathrm{Nd}$ \\
\hline $\begin{array}{l}\text { Rhodococcus } \\
\text { erythropolis }\end{array}$ & $\mathrm{S} 1 \mathrm{R} 2$ & $99 \%(745)$ & high GC Gram+ & 3 & $9.0(1.4)$ & $7.5(2.1)$ \\
\hline $\begin{array}{l}\text { Stenotrophomonas } \\
\text { sp. }\end{array}$ & S1R3 & $100 \%(709)$ & $\begin{array}{l}\text { Gamma- } \\
\text { proteobacteria }\end{array}$ & 2 & $14(1.4)$ & $\mathrm{Nd}$ \\
\hline Pseudomonas sp. & S1R4 & $99 \%(866)$ & $\begin{array}{l}\text { Gamma- } \\
\text { proteobacteria }\end{array}$ & 3 & $5.5(0.71)$ & $\mathrm{Nd}$ \\
\hline Delftia acidovorans & S2E4 & $99 \%(599)$ & $\begin{array}{l}\text { Beta- } \\
\text { proteobacteria }\end{array}$ & 1 & $15(0.71)$ & $\mathrm{Nd}$ \\
\hline Acinetobacter sp. & S2R2 & $99 \%(647)$ & $\begin{array}{l}\text { Gamma- } \\
\text { proteobacteria }\end{array}$ & 1 & $15(0.71)$ & $8.0(0.0)$ \\
\hline Delftia $\mathrm{sp}$ & S2R3 & $99 \%(791)$ & $\begin{array}{l}\text { Beta- } \\
\text { proteobacteria }\end{array}$ & 3 & $2.0(1.4)$ & $\mathrm{Nd}$ \\
\hline Pseudomonas sp. & S2R4 & $99 \%(632)$ & $\begin{array}{l}\text { Gamma- } \\
\text { proteobacteria }\end{array}$ & 1 & $4.0(1.4)$ & $\mathrm{Nd}$ \\
\hline Rhodococcus sp. & S3E2 & $98 \%(835)$ & high GC Gram+ & 3 & $6.0(0.0)$ & $7.5(0.71)$ \\
\hline Rhodococcus sp. & S3E3 & $97 \%(482)$ & high GC Gram+ & 3 & $21(0.71)$ & $38(1.4)$ \\
\hline Flavobacterium sp. & S3R1 & $98 \%(685)$ & $\begin{array}{l}\text { CFB group } \\
\text { bacteria }\end{array}$ & 2 & $13(0.71)$ & $\mathrm{Nd}$ \\
\hline Pseudomonas sp. & S3R3 & $100 \%(685)$ & $\begin{array}{l}\text { Gamma- } \\
\text { proteobacteria }\end{array}$ & 3 & $13(0.71)$ & $13(1.4)$ \\
\hline
\end{tabular}

Homology with the database sequence expressed in \%, numbers of sequenced base pairs are in parentheses.

BATH R2A: cells grown on R2A agar. BATH HEX: cells grown on basic mineral salt agar with hexadecane. Mean values from two independent experiments, estimations of standard deviations (Bliss, 1967) are in parentheses. Nd: Strains were unable to growth on hexadecane.

Growth was evaluated on a scale $1-3$, see Section 2.

Proved strains (12 from 25 initially isolated) were identified by 16S rRNA gene sequencing (Amato et al., 2007). DNA was isolated using Easy-DNA ${ }^{\mathrm{TM}}$ kit (Invitrogen, Carlsbad, US). 16S rRNA gene amplification was carried out by PCR, using 27f (5'-AGAGTTTGATCCTGGCTCAG-3') and 1492r (5'GGTTACCTTGTTACGACTT-3') primers, isolated DNA fragments were sent for sequencing (MWGBiotech, Courtaboeuf, France) and the obtained sequence was analyzed using BLASTN (http://www.ncbi.nlm.nih.gov/BLAST/).

Hydrophobicities of cell surfaces were judged using the BATH test (Rosenberg, 1984). Bacterial strains were grown five days on R2A agar and/or eight days on mineral agar with hexadecane as the sole carbon and energy source (described mineral media components plus $15 \mathrm{~g}$ of agar and $0.4 \mathrm{~g}$ of hexadecane per litre, hexadecane was finally present in emulsion and as a thin surface layer on the agar plates), both cultivations at $25^{\circ} \mathrm{C}$. Cells were then scratched from the medium surface, resuspended in phosphate 
buffered physiological solution (PBS, $\mathrm{pH}$ 7.3), washed twice in PBS and finally diluted to OD 0.5 $(400 \mathrm{~nm})$. An aliquot $(0.8 \mathrm{ml})$ of a bacterial suspension in PBS was added to hexadecane $(160 \mu \mathrm{l})$ and vortex mixed at constant speed for $5 \mathrm{~min}$. Following equilibration, the lower aqueous layer was carefully removed and its OD measured at $400 \mathrm{~nm}$. Three tubes for each strain were measured. The experiment was repeated with newly cultivated cells and almost identical values were obtained. The hydrophobicity is expressed as the percentage of the applied cell suspension OD which had been excluded from the aqueous phase (results in the interval 0-100\%, low value means low hydrophobicity).

Contact angle values of initial and oxidized PE were measured by sessile drop technique using the Surface Energy Evaluation (SEE) System (Advex Instruments, Brno, Czech Republic). Contact angles were measured directly from the images of the solid-liquid meniscus of a liquid drop set on a solid surface. For each liquid the measurement were done for 10 drops. The correction to roughness was not made, i.e., obtained values of contact angle could be higher for the non-wettable materials. Dispersive and polar surface tension components were computed according to Fowkes' theory from the contact angle values of two test liquids i.e. diiodomethane and water.

\section{Results and discussion}

The choice of forest soils was justified by two main reasons: firstly, intensive degradation processes take place in this environment due to rich and active microbial communities; secondly, it was shown that microorganisms present in a forest soil can initiate degradation of similar PE material (Chiellini et al., 2003).

We decided not to put PE directly into contact with soil but first release microorganisms into suspension solution. This procedure assured better access of microorganisms to the PE surface than in a heterogeneous soil environment and also reduced the risk that during the subsequent separation of adhering cells some unwanted microorganisms would be transferred along with a soil particle.

The described isolation and identification procedure finally provided 12 bacterial strains listed in Table 2 . In this study, the majority of isolates belonged to Beta- or Gamma-proteobacteria groups but the incidence of Rhodococcus strains was also important. Among isolated strains, Rhodococcus also covered PE surface with the highest density. However, a striking density of cells was registered with, for example, Pseudomonas sp. S1R4 as well. Pseudomonas and Rhodococcus are among the most studied degraders of various xenobiotics including some very recalcitrant ones. Both genera are also described as producers of biosurfactants important for adhesion and utilization of poorly soluble substances ([Larkin et al., 2005] and [Das and Mukherjee, 2005]). Rhodococci especially has the capacity to degrade larger nonpolar molecules. Other isolated genera Flavobacterium (Brakstad et al., 2004), Delftia (Patil et al., 2006), and Ralstonia (Ryan et al., 2007) were also reported as potent degraders of xenobiotics. Quite surprisingly, no 
fungal or yeast species were isolated. This could be partly because of the procedure of isolation but we believe it also reflects the higher affinity of bacteria species to attach and grow on oxidized PE surface.

An attempt was made to investigate whether the strains could be divided to several groups according to their metabolic capacities. Therefore their metabolic profiles, based on testing of utilization of 33 different carbon substrates on Biolog Eco-plates ${ }^{\mathrm{TM}}$ (Biolog, USA), according to manufacturer's instructions, were compared. Principal component analysis failed to divide the isolated strains into distinguished groups (data not shown).

Surface characteristics of isolated microorganisms could have a crucial role in cell adsorption and utilization of insoluble substances (Orr et al., 2004). Original PE film itself proved highly hydrophobic. After the oxidation treatment, preceding its use in our experiments, its hydrophobicity should be significantly diminished because of the polar chemical moieties formation in the material and on its surface. This was confirmed by contact angle measurement of standard testing liquids and the subsequent calculation of surface tension components (Sprang et al., 1995). After the oxidation treatment, the polar component of surface tension increased by more than three times (Table 3).

Table 3.

Surface characterizations of original and oxidized PE films.

\begin{tabular}{|c|c|c|c|}
\hline Sample & & $\begin{array}{l}\text { Dispersive component of surface tension } \\
\left(\mathrm{mN} \mathrm{m}^{-1}\right)\end{array}$ & $\begin{array}{l}\text { Polar component of surface tension } \\
\left(\mathrm{mN} \mathrm{m}^{-1}\right)\end{array}$ \\
\hline $\begin{array}{l}\text { Original } \\
\text { film }\end{array}$ & PE & $42(0.91)$ & $0.58(0.025)$ \\
\hline $\begin{array}{l}\text { Oxidized } \\
\text { film }\end{array}$ & $\mathrm{PE}$ & $37(1.2)$ & $1.8(0.087)$ \\
\hline
\end{tabular}

Numbers in parentheses are standard deviations.

Surface hydrophobicity of isolated strains was characterized by their partitioning between aqueous and nonpolar solvents, in the so-called BATH assay (Rosenberg, 1984) (Table 2). Cells were grown for the assay either on R2A agar or on mineral agar with hexadecane as a model nonpolar substrate; in cases the strains were capable of its utilization. In general, isolated strains did not appear significantly hydrophobic, with the only exception being Rhodococcus sp. S3E3. When cultivated on hexadecane the latter strain exhibited 38\% hydrophobicity in BATH assay. Rhodococci are known for their ability to form hydrophobic envelopes and metabolize larger nonpolar molecules (Sokolovska et al., 2003.). For other strains, cultivable on hexadecane agar, the hydrophobic substrate did not induce a marked change in their surface properties. It must be admitted that the properties of cells cultivated even on hexadecane media can still differ from those grown on the authentic preoxidized PE surface, but it is technically impossible to collect the quantity of cells necessary for their characterization directly from the PE film surface. 
Accepting, at least partially, the relevance of presented results, the data could suggest that the hydrophobicity of cells and probably hydrophobic interactions did not play a major role in cell adhesion in this case. Non-hydrophobic bacteria sparsely colonizing a similar material was also described by Hadad et al. (2005). In this respect it should be noted that carbonyl, carboxy and hydroxy groups capable of electrostatic interactions or hydrogen bonding are present on the surface of oxidized PE and can mediate such interactions with the cell surface of microorganisms. Production of extracellular substances, acting as an adhesive between a cell and the surface appears relevant. Both pseudomonads and Rhodococci, exhibiting the highest capacity to colonize the investigated material, are known to produce extracellular polymers and biosurfactants.

It can be concluded that, in agreement with other authors ([Bonhomme et al., 2003] and [Orr et al., 2004]), several members of Rhodococcus genus were isolated proving their role in the interaction of preoxidized PE with natural bacterial communities. However, it was shown as well that Rhodococci, or more general actinomycetes, are not a prominent group of microorganisms colonizing the surface of the material. Broader spectrum of isolated taxons showed that the microorganisms capable of adhering to preoxidized PE surface and metabolizing some of its oxidation products are not rare in forest soils and because the identified genera are relatively common, an assumption could be made, that similar results can be expected in other types of soils with rich microbial communities. If the prooxidant technology ensures continuation of the PE chain breakdown process after PE waste disposal, one can expect in soil, such oxidation products to be biodegraded.

\section{Acknowledgment}

This study was partially supported by the Czech Ministry of Education, Youth and Sports, project no. MSM 7088352101.

\section{References}

Albertsson et al., 1993 A.C. Albertsson, C. Sares and S. Karlsson, Increased biodegradation of LDPE with nonionic surfactant, Acta Polymerica 44 (1993), pp. 243-246.

Albertsson et al., 1995 A.C. Albertsson, C. Barenstedt, S. Karlsson and T. Lindberg, Degradation product pattern and morphology changes as means to differentiate abiotically and biotically aged degradable polyethylene, Polymer $\mathbf{3 6}$ (1995), pp. 3075-3083.

Amato et al., 2007 P. Amato, M. Parazols, M. Sancelme, P. Laj, G. Mailhot and A.M. Delort, Microorganisms isolated from the water phase of tropospheric clouds at the Puy de Dôme: major groups and growth abilities at low temperatures, FEMS Microbiology Ecology 59 (2) (2007), pp. 242-254.

Bliss, 1967 C.I. Bliss, Statistics in Biology, McGraw-Hill, New York (1967) pp. 135-136.

Bonhomme et al., 2003 S. Bonhomme, A. Cuer, A.M. Delort, J. Lemaire, M. Sancelme and G. Scott, Environmental biodegradation of polyethylene, Polymer Degradation and Stability 81 (2003), pp. 441-452.

Brakstad et al., 2004 O.G. Brakstad, K. Bonaunet, T. Nordtug and O. Johansen, Biotransformation and dissolution of petroleum hydrocarbons in natural flowing seawater at low temperature, Biodegradation 15 (5) (2004), pp. 337-346.

Chiellini et al., 2003 E. Chiellini, A. Corti and G. Swift, Biodegradation of thermally-oxidized, fragmented, low-density polyethylenes, Polymer Degradation and Stability 81 (2) (2003), pp. 341-351. Chiellini et al., 2007 E. Chiellini, A. Corti and S. D'Antone, Oxo-biodegradable full carbon backbone polymers - biodegradation behaviour of thermally oxidized polyethylene in an aqueous medium, Polymer Degradation and Stability 92 (7) (2007), pp. 1378-1383. 
Das and Mukherjee, 2005 K. Das and A.K. Mukherjee, Characterization of biochemical properties and biological activities of biosurfactants produced by Pseudomonas aeruginosa mucoid and non-mucoid strains isolated from hydrocarbon-contaminated soil samples, Applied Microbiology and Biotechnology 69 (2) (2005), pp. 192-199.

Hadad et al., 2005 D. Hadad, S. Geresh and A. Sivan, Biodegradation of polyethylene by the thermophilic bacterium Brevibacillus borstelensis, Journal of Applied Microbiology 98 (5) (2005), pp. 1093-1100.

Jakubowicz, 2003 I. Jakubowicz, Evaluation of degradability of biodegradable polyethylene (PE), Polymer Degradation and Stability 80 (2003), pp. 39-43.

Khabbaz et al., 1999 F. Khabbaz, A.-C. Albertsson and S. Karlsson, Chemical and morphological changes of environmentally degradable polyethylene films exposed to thermo-oxidation, Polymer Degradation and Stability 63 (1999), pp. 127-138.

Koutny et al., 2006b M. Koutny, J. Lemaire and A.M. Delort, Biodegradation of polyethylene films with prooxidant additives, Chemosphere 64 (8) (2006), pp. 1243-1252.

Koutny et al., 2006a M. Koutny, M. Sancelme, C. Dabin, N. Pichon, A.M. Delort and J. Lemaire, Acquired biodegradability of polyethylenes containing pro-oxidant additives, Polymer Degradation and Stability 91 (7) (2006), pp. 1495-1503.

Larkin et al., 2005 M.J. Larkin, L.A. Kulakov and C.C. Allen, Biodegradation and Rhodococcus - masters of catabolic versatility, Current Opinion in Biotechnology 16 (3) (2005), pp. 282-290.

Orr et al., 2004 I.G. Orr, Y. Hadar and A. Sivan, Colonization, biofilm formation and biodegradation of polyethylene by a strain of Rhodococcus ruber, Applied Microbiology and Biotechnology 65 (1) (2004), pp. 97-104.

Patil et al., 2006 N.K. Patil, R. Kundap, Y.S. Shouche and T.B. Karegoudar, Degradation of plasticizer di- $n$-butylphthalate by Delftia sp. TBKNP-05, Current Microbiology 52 (5) (2006), pp. 369-374.

Rosenberg, 1984 M. Rosenberg, Bacterial adherence to hydrocarbons: a useful technique for studying cell surface hydrophobicity, FEMS Microbiology Letters 22 (3) (1984), pp. 289-295.

Ryan et al., 2007 M.P. Ryan, J.T. Pembroke and C.C. Adley, Ralstonia pickettii in environmental biotechnology: potential and applications, Journal of Applied Microbiology 103 (4) (2007), pp. 754-764.

Sivan et al., 2006 A. Sivan, M. Szanto and V. Pavlov, Biofilm development of the polyethylene-degrading bacterium Rhodococcus ruber, Applied Microbiology and Biotechnology 72 (2) (2006), pp. 346-352.

Sokolovska et al., 2003 I. Sokolovska, R. Rozenberg, C. Riez, P.G. Rouxhet, S.N. Agathos and P. Wattiau, Carbon sourceinduced modifications in the mycolic acid content and cell wall permeability of Rhodococcus erythropolis E1, Applied and Environmental Microbiology 69 (12) (2003), pp. 7019-7027.

Sprang et al., 1995 N. Sprang, D. Theirich and J. Engemann, Plasma and ion beam surface treatment of polyethylene, Surface and Coatings Technology 74-75 (2) (1995), pp. 689-695.

Sudhakar et al., 2008 M. Sudhakar, Mukesh Doble, P. Sriyutha Murthy and R. Venkatesan, Marine microbe-mediated biodegradation of low- and high-density polyethylenes, International Biodeterioration and Biodegradation 61 (3) (2008), pp. 203-213.

Vaclavkova et al., 2007 T. Vaclavkova, J. Ruzicka, M. Julinova, R. Vicha and M. Koutny, Novel aspects of symbiotic (polyvinyl alcohol) biodegradation, Applied Microbiology and Biotechnology 76 (4) (2007), pp. 911-917.

Wiles and Scott, 2006 D.M. Wiles and G. Scott, Polyolefins with controlled environmental degradability, Polymer Degradation and Stability 91 (7) (2006), pp. 1581-1592. 